\title{
For Japan, Better Late Than Never
}

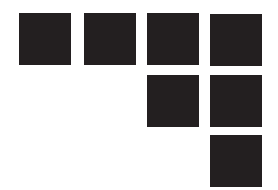

\section{William Gerding, \\ Cornell University, 2013, Classics Major \\ Zach Montague, \\ Cornell University, 2013, Government Major}

The Japanese general election on August 30, 2009 ousted the Liberal Democratic Party (LDP), which had governed almost uninterrupted for 54 years. In its place rose the Democratic Party of Japan (DPJ) and its leading man Yukio Hatoyama. What follows is a brief profile of the DPJ's main economic challenges and policies, succeeded by the chief points of contention in the DPJ's interpretation of Japan's alliance with the US, the invariable focus of which is military. Now, Japan finds itself at a crucial junction to reassert itself as a regional leader in Asia, whether military or civilian, and it can only do this gracefully by maintaining a relatively undisturbed rapport with the US in economic and military matters. Japan also needs to increase its presence in the Asian economies and, possibly, Asian military affairs, a policy that the US would condone.

\section{New Government and Domestic Challenges}

The road to success for the DPJ in this year's elections was not unlike that of the Democratic Party in the US. In the wake of the global financial crisis, both parties emerged riding the wave of popular discontent with the party in power. In their leadership, the young and smooth-talking Barack Obama greatly resembled the quirky and unorthodox Hatoyama, both in persona and rhetoric. It was clear from campaigning and advertising that both men aggressively promoted the public perception that their party represented great ideological shifts in their respective states' domestic and foreign policy. However, with both parties now in power, and in control of the world's two largest economies, it is becoming clear that the DPJ has stepped into a domestic situation completely unlike that of the US, or indeed the rest of the developed world.

Having unseated the rival LDP, which dominated Japanese politics since 1955, the word "change" as used by the DPJ has connotations far deeper than the word embraced by the ObamaAdministration during the presidential campaign. For many Japanese, the last three decades can be characterized by growing income disparity, unconceivable government spending, and a national debt of over $\$ 10$ trillion that some theorists now think capable of breaking the economy. With a debt-to-GDP ratio approaching 2:1 left over from the previous administration, the public call for change to Hatoyama has been to somehow stabilize the domestic economic situation while maintaining a high standard of living and social welfare system.

So far, the government's answer has been to make widespread cuts in the extensive public works projects embraced by the previous party, such as the 48 government-financed hydroelectric dam projects the DPJ has announced plans to abandon. ${ }^{1}$ These expensive civil engineering projects that proliferated in the postwar era have been accused of allowing pork barrel spending, and blamed for funding "road to nowhere" construction that yields little social benefit. Analysts have argued that the broad social welfare system modeled after the European one, which the DPJ hopes to create with the funds cut from construction projects, will ultimately turn out to be far more costly than the public works it will replace. Thus, the borrowing will have to continue in quantities something to the tune of $\$ 550$ 
billion as stipulated by the Japanese finance minister on October 20th. ${ }^{2}$ With tax revenue as low as it is, this dependence on the sale of government bonds as the primary means of income is worrisome at best. Implications of this alarming trend in the national debt boiled to the surface last year, when the interest payments consumed over a fifth of the government budget. ${ }^{3}$

Considering that the sectors of the population the DPJ has relied on for support include the unemployed, and the socioeconomic underclass, to whom the party has promised many benefits, stabilizing government spending should be a priority for the fledgling DPJ. Among these promises were pledges of increased spending on healthcare, child support, public secondary education, and guaranteed minimum pensions. ${ }^{4,5}$ There is no indication that Japan will be able to regain any semblance of control over its national debt, much less institute any meaningful welfare advances, until it manages its spending more deftly. As of now, it seems that the steps Japan's leadership must take to rein in the economy are unlikely to be as comfortable as much of the population would like. The reality Japan now faces is that increased spending may not be the key to economic recovery, or at least in the same way it has been employed

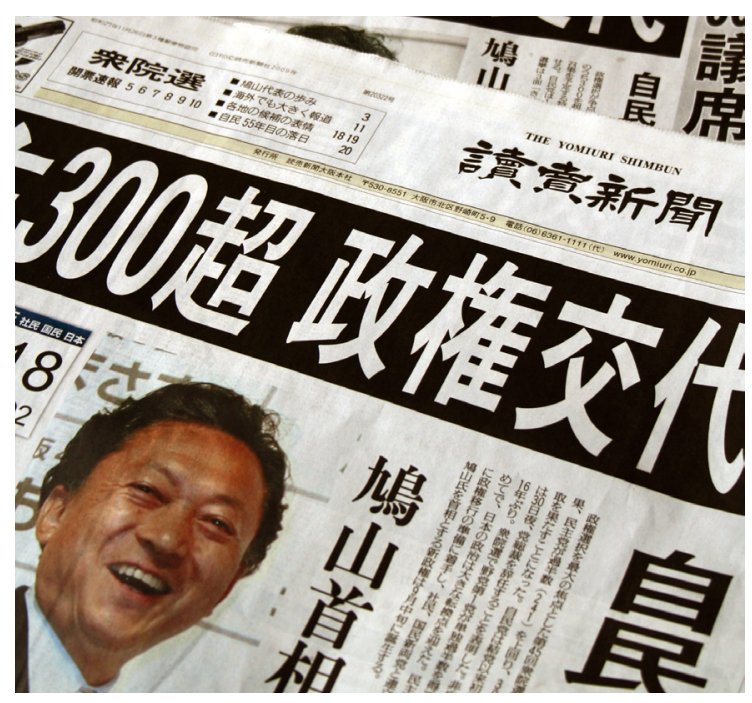

Papers announce the victory of Yukio Hatoyama, the current Prime Minister of Japan in countries like the US. It is entirely possible that steps to economic recovery will resemble something closer to the period of toil predicted by former Prime Minister Junichiro Koizumi, which may have to focus less on moderate policy transition, and more radical reform.

\section{Economic Interests Abroad}

Despite the panic and uncertainty the Japanese economic situation has caused at home, it is a prime opportunity for the young DPJ to step up to the plate on financial foreign policy. Neither the lingering effects of the global financial crisis, nor its inherited economic problems have limited the new party so far from playing its traditional role as a key world power, and may ultimately be a chance for it to forge stronger ties in the future.

We have not yet seen enough from this government to analyze its foreign economic policy, but it has identified several goals that will prove essential to its success in the future if realized. They are effectively summarized by the DPJ's slogan for foreign and economic policy: nyua nyuou (enter Asia, enter the West). ${ }^{6}$ The first is to maintain amicable economic relations with the US, which it hopes will continue to be a close trading partner throughout hard economic times. The second is to strengthen cooperation within Asia, more specifically between Japan, China, and South Korea, in an attempt to draw these countries' economies closer. How Japan conducts its foreign relations in the years to come will be closely tied to its economic situation, and may be crucial in facilitating its recovery.

Especially in light of US-Japanese tensions over Japanese military policy, the DPJ has strived to improve relations between the two, encouraging increased bilateral trade. Most immediately, party officials have promised prompt negotiations on a new free-trade agreement between the two states, ${ }^{7}$ and have declared long-term plans to improve Japanese economic institutions still to be planned out. Obviously, the support 
from the US will continue to be intrinsic to Japan's overall economic health, and losing economic cooperation because of political disputes would be a staggering blunder for the new administration. However, good relations between the Obama administration and the DPJ could translate into more than just economic recovery. Experts on Japanese foreign policy such as Sheila Smith have observed that domestic turmoil over the last few decades has caused declining interest in global affairs. ${ }^{8}$ She, along with others, have predicted that the strategy to strengthen Japan's bilateral agreements with the US may effectively push Japan into a role of greater participation in international affairs. ${ }^{9}$

The bigger prospect for Japanese long-term gain lies in relations between Japan and China. Secretary General Katsuya Okada of the DPJ has stated publically that his party believes the two states must strengthen economic cooperation and maintain closer communication in order to wield greater collective influence in world affairs. ${ }^{10}$ However, the party has declared much larger ambitions than simply stronger relations between Japan and China. In its party platform, the DPJ calls for "proactive diplomacy," or more specifically, to "establish intra-regional cooperative mechanisms in the Asia-Pacific region with the aim of building an East Asian Community."11 The so-called "East Asian Community" as described by Hatoyama would potentially involve a future regional currency union, and a system possibly resembling something close the European Union. ${ }^{12}$ Many of the region's governments are not opposed to this movement: on October 25, 2009 at the $4^{\text {th }}$ summit of the Association of Southest Asian Nations (ASEAN) the chairman included in his closing statement that the ASEAN nations "acknowledged the importance of regional discussions to examine ways to advance the stability and prosperity of the Asia Pacific region. In this connection, we [the members] noted with appreciation... Japan's new proposal to reinvigorate the discussion towards building, in the long run, an East Asian community based on the principle of openness, transparency and inclusiveness and functional cooperation." ${ }^{13} \mathrm{~A}$ close interpersonal connection between South Korean President Lee Myung-bak and Hatoyama has led to a fruitful relationship between the two nations,

\section{"Support from the US will} continue to be intrinsic to Japan's overall economic health, and losing economic cooperation
because of political disputes
would be a staggering blunder
for the new administration."

and secures the prospect for tightening relations, both politically and economically in years to come.${ }^{14} \mathrm{Clearly}$, the ability to persevere throughout this bleak economic period will designate Japan and its new government as a leader among the Asian states, and push it closer to this goal of greater regional cooperation in the future. While this goal may be distant for the time being, it nonetheless offers great insight into the intentions of the DPJ with regard to its foreign policy.

There are two main ways that Japan can reclaim its status as an economic leader in Asia. The first is through maintaining its high export levels. Its constant dependence on exports may have contributed to Japan's quick reemergence from the global recession, as it was in the case of Germany. Yet both the DPJ and the Japanese populace understand that its current-account surplus is unsustainable due to the yen's buoyancy - Japan is the only Asian state that doesn't artificially undervalue its currency ${ }^{15}$ - and unhealthy for the Japanese economy. By encouraging low production costs and labor-wages and allowing the owners of businesses to horde profits, Japan reinforced the income inequality ushered in by the lost decades of the 1980s and 1990s, when an asset price bubble cratered and plunged the entire economy into a complete 
standstill. It also deepened the rift that began in the lost decades between large, extremely profitable firms and small, floundering business, a further agent of unequal income distribution. ${ }^{16}$ Hatoyama sees the account surplus, along with the nation's new income inequality, unemployment, and homelessness, as remnants of Junichiro Koizumi's policy of "unrestrained market fundamentalism and financial capitalism,"17 words which he pronounces in a disapproving tenor.

The second approach is to reassert itself as a financial investing power in Asia. Three economic policies are required for this to happen effectively. The first policy is to encourage the appreciation of the yen. The DPJ seems to favor this, if with some hesitation. Any reticence they feel is on behalf of the exporting farmers, carmakers, and electronics firms who benefit from the weak yen in so far as it gives them a competitive price-advantage. ${ }^{18}$ Yet only when the yen has a stronger purchasing-power will Japan be able to invest in neighboring Asian markets, and, in this competitive arena of investment, it will be able to trump China, whose exportdependence demands Beijing to artificially undervalue and peg the yuan to the dollar. This would establish a robust Japanese investmentdriven economy as a foil to the Chinese exportdriven economy and would grant Japan all the political sway that attends an investor-nation whose economic presence in neighboring markets has become essential to those nations. This investment is the second policy to reclaim its former economic position in Asia. Once Japan has invested abroad, it will be able to maintain more stable growth. Moreover, once it has secure investments, Japan will definitely be within reach of accomplishing its third economic policy: balancing its currentaccount surplus, an effort that would require a large increase in domestic consumption and import as well as a strong curtailment of Japanese exports. The appreciation of the yen that will follow investment will also boost domestic consumption and import, through the currency's new purchasing power. To speed this process, Hatoyama has already taken a step towards improving consumption by proposing to lower business taxes and rates (though this has caused some logical unease in economists who cannot reconcile this picture with the country's huge amount of debt). ${ }^{19}$ Investment alone will not balance the current-account surplus - in fact, it may exacerbate it. The reason why an investmentdriven economy would lead to a more even current account is that, unlike an exportdriven economy, the appreciation of the yen that would follow investment would be sustainable. Since Japan is currently a major exporter, the appreciation of the yen that results from a strong export-economy is disrupting the continued sale of goods abroad. There is tension in Japanese business between the strength of the yen and the economy's dependence on exports. The major shift towards investment would dissolve this tension.

Now is the time for Japan to capitalize on this opportunity. Because the yen is on the rise ${ }^{20}$ and other countries' economies are struggling, there is an investment vacuum in many of the Asian nations. This window will not last for long, as Forbes already predicts that by early 2010 a new wave of Asian foreign direct investment will begin. ${ }^{21}$ This is the optimal chance for Japan for buy into Asian markets abroad and reestablish itself as an economic power and stabilizer in that region of the world.

It is important to note that this issue of Japanese leadership and greater regional cooperation could be one of mild tension. This is particularly due to the commonly antagonistic competition in the international economic atmosphere and the lingering anxiety across all countries about the implications of global recession. Due to Japan's great historical importance as a major exporter, the leaders of the DPJ must be cognizant of the weight they throw around in international relations. With China and the US not always completely at 
ease with one another's role in their economic relationship, Hatoyama and his administration must be certain not to alienate either state with any behavior that could resemble preferential treatment. To illustrate the sensitivity of the situation, the Obama Administration has already expressed its concern that it be included fully in whatever movement towards increased economic integration in Asia might come of Japanese diplomacy with China and South Korea, proposing a summit meeting with the leadership of all the nations involved. ${ }^{22}$ The US has recently been on the defensive, scrambling to increase diplomatic relations between the itself and Japan amidst remarks by Hatoyama emphasizing less reliance on the US and more cooperation within Asia. Representing such a large economic force, it would be unwise for Japan to act impulsively with regard to its foreign economic policy, as both the US and China look to Japan as a financial powerhouse and much-desired ally.

\section{Clearly, the ability to persevere throughout this bleak economic period will designate Japan and its new government as a leader among the Asian states}

Since China has responded less than enthusiastically to Japan's visions for economic union within Asia, it would be in Japan's best interest to think more individually and do some inward reflection before seeking demanding commitments abroad. Still slightly unsure of its role in the global economic playing field both now and in years to come, and saddled with domestic economic problems, Japan is undeniably at a critical crossroads. For its new leadership, this is an opportunity to remake Japan to the same extent as after WWII, and should be viewed and handled as such. However despite this great potential, the DPJ is playing a high-stakes game and may indeed face financial disaster should it mismanage its domestic or foreign policy.

\section{The Two States}

Change has come to Japan, and this invariably involves military reform. This is because the real guarantor of Japanese security is not the Japanese military, the framework for which was outlined by the US after WWII and which is unambiguously defined as a self-defense force. Japanese security explicitly lies in the US' nuclear umbrella and the presence of nearly 50,000 American troops in Japan, the result of a postWWII status-of-forces agreement between the two powers; this explains the US' interest in the matter. That the DPJ would want to promise a decreased dependence on the US for Japan's defense only stirs anxieties in Washington. Yet Hatoyama's cabinet has not failed to express that the main focus of their new military agenda easily fits under their desire for an "equal" relationship with the US. In fact, this insistence on "equality" has only arisen in topics concerning American military presence. The Japanese do not want all of America's troops to clear the archipelago. They do not want to be left by the force through which they have been able to limit their defense spending to $1 \%$ of GDP. ${ }^{23}$ And though the specifics of what Hatoyama's administration will be proposing on this subject are vague, it is clear that the DPJ do not want to evict all of the US troops stationed in Japan.

Though the detailed opinions held by the cabinet are unknown, it is evident which areas of reform the DPJ members have been discussing. Most do not want to fulfill the troop realignment pact as agreed. The pact that Japan and the US wrote up under the LDP in 2006 records the planned relocation of a helicopter base and Marine Corp troops from Futenma in one area of Japan's southern island prefecture of Okinawa to Nago, another location on the same island. ${ }^{24}$ Hatoyama has stated clearly his wishes that the troops be located somewhere off the island. It took over a decade of retooling for this pact to be accepted by both the US and Japan; needless to say, the lost progress is disheartening to the 
US. The process of revising this clause of the "Roadmap for Realignment Implementation" 25 would be immensely time-consuming, a quality of international policy that the U.S. - because it has so many interests in regions such as East Asia - hopes to evade as much as possible. Furthermore, because of the absolutism of the issue, it will be very hard to define a compromise; the base, after all, is either on or off the island. Such prospects notwithstanding, Hatoyama unswervingly asserts his confidence in the American military presence in Japan; on October 21, 2009 he told US Defense Secretary Robert Gates that "under the circumstances in which uncertainties remain in this Northeast Asia region [referring to North Korea and China], I think it is imperative to maintain and develop our alliance even further." ${ }^{26}$ As far as the US is concerned, it seems that Gates will not allow any change of plans: the displeasure of local residents with the noise, pollution, and other disruptions which they attribute to the base that constitute the grounds for Japanese resistance to continued presence in these districts of Okinawa falls far lower on America's list of priorities than does the proximity of having a base so near mainland China.

A second competition of wills between Japan and the US concerning military power has emerged from another clause in the same "Roadmap of Realignment Implementation" signed in 2006. This clause, immediately following the statement of the relocation of the helicopter base in Okinawa, maintains that of the costs generated by the relocation of 8,000 Marines and their 9,000 dependents from Okinawa to Guam by 2014, Japan will foot $\$ 6.09$ billion of the expense. Tokyo feels that Japan should not be made to shoulder such a heavy price. The movement of troops was arranged with a look towards China's growing military strength. That Japan and the US share the desire for an American check to China's power is undeniable. However, though Hatoyama does want troop retrenchments in Japan, it is not unimaginable that he would feel indignant that the Japanese should have to pay the lion's share for a relocation of troops from their country. This becomes even clearer if one notes that this removal of armed forces would situate troops over 1,500 miles away from mainland Japan. At present the troops are on the islands, ready to be at hand in the second after the alert for the defense of Japan. Hatoyama is not upset that the troops are relocating; he's simply galled that this clause of the "Roadmap of Realignment Implementation" forces the Japanese to pay for a decrease in their immediate defense.

The third point of contention between the US and Japan is also largest and potentially the thorniest. Hatoyama has expressed loudly that he feels the Japanese constitution should be amended, including Article 9, which bars the Japanese from warfighting and relegates its small armed force to its current position of Maritime Self-Defense Force. ${ }^{27}$ To what degree he would currently like to temper Article 9 is unclear, and to what degree the Japanese Diet (their parliament) would approve is essentially unknown. Though this has caused much understandable anxiety in Washington, one might call its true rationality under question: Hatoyama has not called for the dissolution of Article 9 or the Maritime Self-Defense Force, after all. Furthermore, nowhere does Hatoyama suggest that any newly militarized force would be offensive or that, if Japan were allowed to build its own forces, it would proportionately expel American troops. This may in fact be the right time for Japan to ratchet up its armed forces if ever there will be one: it will certainly send a strong, deterrent message to North Korea if Pyongyang sees both US and Japanese troops manning bases along the archipelago, if not only because of the growth in numbers, also because expanded Japanese forces would guarantee the permanence of the military check from Japan on North Korea. Permission for the Japanese to grow their defensive forces would also finally capitalize on the window of opportunity which the U.S. has forced Japan to waste since the late 1970s, 
when China's army first began modernizing and multiplying. If Japan could decrease the relative military power of China by any degree, it would be in America's interests; though Washington itself prefers to tower above all other military powers, it should sooner encourage Japan to help check China then have itself suffer an additional loss of relative military strength through inaction.

It is not unreasonable that the Japanese should want to expand their defensive military forces as regards their own security. Washington does not need to misapprehend this as a threat. More than an attempt on Japan's part to build any military capability against the US, this indicates a fear the Japanese have concerning the US priorities. As the image of American power and influence begins to dissolve in an international scene of rising multipolarity, Japan is beginning to feel anxious about the difference between the US' immediate desire for demilitarization in East Asia and Japan's desire for its own long-term security and the persistence of a Japanese defense capability if, on some distant day, America should no longer be a power-player in Asia. In an op-ed in the New York Times, Yukio Hatoyama himself voiced this conviction of America's gradual decline, writing that "I [Hatoyama] also feel that as a result of the failure of the Iraq war and the financial crisis, the era of U.S.-led globalism is coming to an end and that we are moving toward an era of multipolarity"28. Japan seems also to be concerned about Washington's current priorities: with redoubled efforts in Afghanistan and talks of a troop increase, Tokyo wonders where it ranks in the U.S.'s list of military resource allotments. And how quick would the response be to an alert raised in North Korea? Though Washington would undoubtedly reassure Japan on all these measures, it is entirely possible that Japan, in accordance with the international institution of states to grasp after self-help, should be worried.

It is also noteworthy in this vein that the DPJ holds unanimously that Japan does not want to develop nuclear weapons. Hatoyama advocates loudly for global non-proliferation. $\mathrm{He}$ has rebuked several overtures from North Korea for sanction-lifts and economic cooperation and has confirmed that he will neither normalize relations with Pyongyang nor deviate from the last administrations hard line towards North Korea's nuclear and missile aspirations ${ }^{29}$. This repudiation of nuclear weapons - a sentiment deeply rooted in Japan's history, being the only state to have undergone nuclear attack - has even reached such a pitch that the DPJ members are still debating among themselves about the procedure for the storage, transshipment, and operation of the US'nuclear weapons in Japan ${ }^{30}$ ${ }^{31}$. If any of these policies of the DPJ ought to be unsettling to Obama's administration, it should be that the new administration feels ambivalent about housing America's nuclear arms.

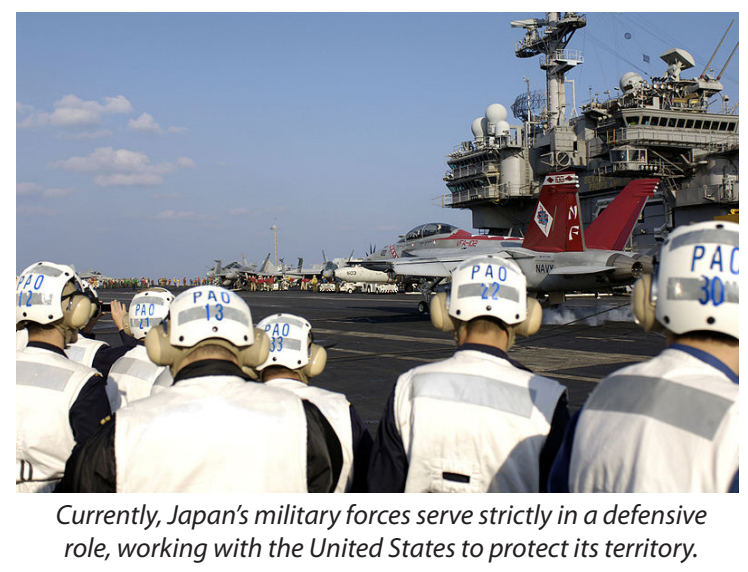

Two more positions the DPJ has held - but has also abandoned - are worth noting, if only for understanding the party's lineage. It has since abandoned both. First, this is not the first time the DPJ has questioned the LDP's approach to Article 9. Throughout its political career the DPJ's leaders, especially Ichiro Ozawa, strongly criticized the use of the Japanese Maritime Self-Defense Force in UNauthorized operations. Ozawa declared this a direct violation of the nation's everlasting relinquishment of war as stated in the article. 
The rest of the DPJ, though not so outspoken as Ozawa on the controversial issue above, have taken issue with the use of the Maritime Self-Defense Forces in antipiracy operations in the Gulf of Aden and the Indian Ocean surrounding Somalia. ${ }^{32}$ In the 2009 election manifesto of the DPJ, however, it reads that the DPJ will "play a proactive role in UN peacekeeping operations" ${ }^{\prime 33}$.

The second renounced point was the Japanese participation in refueling missions for the US-led forces in Afghanistan. These operations used the Maritime Self-Defense Force as a fleet of fuel-taxis that refilled the coalition in the Indian Ocean. It is essential to the efficiency of the war effort that the Japanese continue this cooperation, though it did cause some concern amongst DPJ members as to the legitimacy of these actions as wise foreign involvements and under Article 9. Though it has opposed such missions, it has accepted them for now. More might be said on this issue, however, in January, when the law allowing this assistance is set to expire ${ }^{34}$.

Though the DPJ has stated these areas of reform, as a nascent administration only recently assuming power they have not intimated what degree of reform they hope to undertake. Furthermore, it can be confirmed that they will make no dramatic change without including the US and, in all likelihood, without proposing it first to Obama's administration before Tokyo's own Diet. Hatoyama has never softened in his dedication to "building constructive, futureoriented relations with the Japan-US alliance as the cornerstone ${ }^{\prime \prime 35}$, nor does Washington have any reason to expect such wavering.

In light of these concerns of the DPJ, it should be mentioned that, if Japan is going to reassert itself as a leading power in Asia, it needs to do so under this administration and in tight step with the US. Any breakdown in communication or cooperation between the two states would be detrimental to both, though obviously more so to Japan. Accordingly and in absolute terms, Japan should sooner accept American terms than sever itself from the U.S. alliance, though there are very few issues in which the US should be entirely inflexible. Japan will not have much more time to act and reassert itself as a leading power in Asia. China has long surpassed it as the military power of the East, as per America's interference. (Whether this interference was in America's long-term interest is not nearly as important as addressing how America will continue to promote stability in Asia through its influence with Japan and other nations.) China will soon outstrip Japan as the world's second largest economy ${ }^{36}$. The emergence of China has detracted from Japan in these two spheres that historically Japan has dominated. It is in both the US' and Japan's shared interest that Japan rise to its previous position of regional leader and stabilizer. Japan needs to remind America that, as far as Washington is concerned, better Tokyo than Beijing in all foreign policy matters. This preference should be seen as a path-dependent result of Japan's history as the US's prominent eastern Cold War ally and of the transparency that has prevailed in all rapport between Japan and the US since the Allied occupation after WWII. Japan needs to stabilize its economic growth and raise itself up as an Asian economic leader by balancing its account surplus, strengthening the yen, and investing in neighboring markets. Japan needs to reassure the US that its policy of "enter Asia, enter the West" reaffirms and secures America's influence in Asia. It should be a selfreinforcing alliance that is forged between the Tokyo and Washington: Washington should promote Japanese regional influence and grant it limited military independence, and Tokyo, through its privileged status as America's liaison in Asia, should uphold America's interests for stability, security, and the continued presence and role of the US in Asian military and economic decisions ${ }^{37}$. 